Pro-Fil 22 (2) 2021: 78-80

https://doi.org/10.5817/pf21-2-2385

\title{
NOAM CHOMSKY - MARV WATERSTONE, CONSEQUENCES OF CAPITALISM: MANUFACTURING DISCONTENT AND RESISTANCE
}

Haymarket Books, 2021, 400 p.

\author{
SERHIY KISH
}

University of West Bohemia, Pilsen, Czech Republic, kishs@kfi.zcu.cz

BOOK REVIEW

The coronavirus pandemic prompted vast questioning of capitalism's ability to adequately react to big crises. Considering this, the release of Noam Chomsky's and Marv Waterstone's book, Consequences of Capitalism: Manufacturing Discontent and Resistance (2021), is indeed timely. It is timely because it tries to help us understand the situation we are in right now. The situation being, to name only one example, our inability to distribute covid vaccines equally among rich and poor countries, which, arguably, should be our priority as "no one is safe until everyone is" (Phillips 2021).

The book is based on the authors' course called What is Politics?, which they have held at University of Arizona for many years now. It consists of seven main chapters and an addendum about capitalism's reaction to coronavirus pandemic. Each of the seven chapters is divided into two parts. In the first one, Waterstone sets out the "theory" of the discussed topic. In the second, Chomsky, drawing on historical reports and articles in influential journals, illustrates said theory on the workings of real-life world. Furthermore, a list of "course readings" is given with each main chapter and a list of "further resources", which was added only to the book, is at the end.

I will explain the first chapter in a closer manner to show the structure of the book. The first chapter considers the notion of "common sense" or "the taken-for-granted" and its relationship to "power" (11). According to Waterstone, common sense is a way of thinking which underlines our societal behavior. By having a common sense "we come to take the rules of everyday life for granted" (15). Further, there is not one common sense but many and each of them is a subject of ongoing creation and modification. Common sense can become an "extremely powerful political tool" if it has the ability to convince people that its way is "the way [the world] ought to operate" (25, emphasis added). This is so because everything outside of prevailing common sense is literally "nonsense" - it is not spoken about (26). The setting of common sense is done mainly by mass media as Chomsky illustrates in the second part of the chapter.

One case in point is US media's evaluation of 2003 invasion of Iraq. In no major media outlets, Chomsky claims, can we find it called "the supreme international crime" or anything like that (58). We cannot find it, arguably, because such description significantly deviates from US' common sense. The biggest deviation from this common sense in evaluating the Iraq invasion was former US president Barack Obama who called it "a strategic blunder" (58). Chomsky notes that Obama is praised for having done so and asks if we would have praised Soviet Union in the same way, had it called the invasion of Afghanistan "a strategic blunder". Whatever is 
the answer, "these are all things that it wouldn't do to say or think about under the reign of hegemonic common sense" (59). Such are the ways and mechanisms by which the boundaries of what is an acceptable discussion are set. I will go through the rest of the book in less detail as its structure will have been clear by now.

The next chapter considers today's most prevailing common sense: "capitalist realism" (63). Using Marx's analysis of capitalism, Waterstone shows that this common sense is based on accumulation of wealth by exploitation of workers. It is not unexpected that according to this common sense "everything in society should be run as a business" (75). And as everything is paid for, people must either accept working for a wage or "starve" (105). Chomsky amounts this to a modern-day slavery on couple of places. Capitalism's focus on making profits is the main setter of our societal dynamics today. The rest of the book is an exploration of the consequences of this common sense.

One of the industries closely resembling a "business" is US military. One example of this is Chomsky's claim that "market fundamentalism" was the main driver behind the US-backed coup of Chilean social democratic government in 1973 (89). The coup was conducted so the "Friedmanite policies", named after famous economist Milton Friedman, could have been established. This resulted in a dictatorship maintained with the help of multination corporations which were making huge profits thanks to the mentioned policies. It is in this way that militarism is closely connected to capitalism. Military makes "the world safe for American corporations" (128-129). This is also the reason, according to authors, behind US's keeping its population in fear by always having an enemy. That is what keeps "military industrial complex in business" (127).

The relationship of capitalism and environment is also touched upon. This relationship is "utilitarian". Nature is commodified in a way for it to be useful to humans. This excessive utilization accelerated climate change and fossil fuel companies knew it: "[Exxon] confirmed the global warming consensus in 1982 with in-house climate models" (208). But doing anything with it would have been against Exxon's interest, so later, in 1988, they began "to pour money into denialism" (217). ${ }^{1}$ The science on climate change was made murky because of profits. We, arguably, are starting to feel the consequences of this denialism (Sengupta 2021).

The talk of capitalism cannot be whole without mentioning neoliberalism and globalization. Neoliberalism is "the set of ideas and practices, [...] a philosophical understanding of how the world not only works, but how it ought to work" (234). One could understand neoliberalism as a particular manifestation, a particular "set of ideas and practices", of capitalism. The conceptual distinctions are not as important as the fact of neoliberalism's need of growth and expansion the result of which is globalization. A case in point is, again, Iraq in 2003. The US wanted to enforce foreign control over "all areas of the economy" in Iraq with the pretense of the "spreading of democracy and freedom" (254). The reality was different: interventions were supposed to result in "a state apparatus whose fundamental mission was to facilitate conditions for profitable capital accumulation" (254). This is how (and why) neoliberalism expands.

The last two chapters have more of a prescriptive goal. They are about how people should endeavor to bring about a social change. It is sometimes claimed that people's activism is futile, but authors stress that it is not so: "even in the face of a seemingly unassailable hegemony, discourses and practices can be shifted through conscious effort" (350). The enormously successful Civil Rights Act of 1960s is the evidence of it. Campaigns for a living wage at some places in the US is another one. If we are going to be saved, it will be with a "vibrant and

\footnotetext{
${ }^{1}$ Which was recently confirmed by Exxon's own lobbyist (Tabuchi 2021).
} 
dynamic organized labor movement" as only that is what "spearheaded progress throughout modern history" (334). Civil involvement is an always necessary part of human emancipation.

This message is stressed once more in the concluding addendum about coronavirus and capitalism. According to the authors, most of the financial reliefs and subsidies at the beginning of the pandemic were given to large corporations and "mere crumbs" went to public (377). One of the ways this happened was by giving the funds to employers rather than workers. This allowed employers to choose "whether to keep workers on the payroll, at what levels of employment, and at what rates of pay" (378). Essentially, the worst-hit were the last thought of when it came to allocation of reliefs. The focus was on profits, not the people.

But the authors do not end on this grim note. On the contrary, they view the upshot of the pandemic as yet undecided: either we bring about new "more humane common sense" or return to the status quo. "Everything depends on the actions that people take into their own hands" (381).

The book is a piece of advocacy. It is something to be stood on by those of us who are not happy with the world as it is. Books should undoubtedly do that, but what about university courses? I cannot imagine a course like that of Chomsky's and Waterstone's, the one they based their book on, being taught at Czech universities. Is it for them something not worth wanting? Or should it, perhaps, be an inspiration?

The bleak tone of the book also needs attention. The passages, especially those about environment, are sad and authors do not pretend otherwise. The emotion of the book is not for everybody. It is not for believers of the notion that scholarly work should not have emotional matter in it. But is it possible to not be emotional after seeing the Consequences of Capitalism? A "food for thought" as Chomsky likes to say.

\section{Bibliography}

Chomsky, N. - Waterstone, M. (2021): Consequences of Capitalism: Manufacturing Discontent and Resistance, Haymarket Books.

Phillips, L. (2021): We Need a Movement Against Vaccine Apartheid, Jacobin [online], [accessed 2021-07-29], available at: < https://jacobinmag.com/2021/07/we-need-an-anti-vaccineapartheid-movement >.

Sengupta, S. (2021): Climate Change Comes for Rich Countries, The New York Times [online], [accessed 2021-08-02], available at: < https://www.nytimes.com/2021/07/21/climate/nyt-climate-newsletter-wildfires-disasters.html $>$.

Tabuchi, H. (2021): In Video, Exxon Lobbyist Describes Efforts to Undercut Climate Action, The New York Times [online], [accessed 2021-08-02], available at: < https://www.nytimes.com/2021/06/30/climate/exxon-greenpeace-lobbyist-video.html >.

This work can be used in accordance with the Creative Commons BY-NC-ND 4.0 International license terms and conditions (https://creativecommons.org/licenses/by-nc-nd/4.0/legalcode). This does not apply to works or elements (such as images or photographs) that are used in the work under a contractual license or exception or limitation to relevant rights. 